\title{
PEMBELAJARAN BERBASIS PROJECT UNTUK MENINGKATKAN PRESTASI BELAJAR SISWA DI SMA NEGERI 6 YOGYAKARTA
}

\author{
Andriyani Triwulandari \\ SMA Negeri 6 Yogyakarta \\ andriyani73tri@gmail.com
}

\begin{abstract}
Abstrak
Peningkatan kualitas pendidikan merupakan tujuan dalam pembangunan pendidikan nasional kita, guru sebagai pendidik perlu lebih memperhatikan dalam memilih metode mengajar yang efektif dan efisien untuk mencapai hasil secara optimal. Penelitian ini bertujuan untuk mengetahui: 1) peningkatan prestasi belajar siswa dengan pembelajaran berbasis project pada mata pelajaran geografi kompetensi dasar dinamika hidrosfer dan dampaknya terhadap kehidupan; 2) peningkatkan aktivitas siswa dalam pembelajaran geografi kompetensi dasar dinamika hidrosfer dan dampaknya terhadap kehidupan. Penelitian ini merupakan penelitian tindakan kelas (Classroom Action Research). Pendekatan penelitian ini adalah pendekatan kualitatif. Penelitian dilakukan di SMAN 6 Yogyakarta tahun pelajaran 2019/2020. Subyek penelitian adalah guru dan siswa kelas X IPS SMAN 6 Yogyakarta, yang berlangsung dalam dua siklus yang masing-masing meliputi empat tahap, yaitu : 1) Persiapan Tindakan, 2) Pelaksanaan Tindakan, 3) Pemantauan dan Evaluasi, dan 4) Analisis dan Refleksi. Hasil penelitian menunjukkan dengan diterapkannya pembelajaran berbasis Project pada mata pelajaran geografi kompetensi dasar dinamika hidrosfer dan dampaknya terhadap kehidupan 1) terjadi peningkatan ketuntasan belajar siswa dari 54\% menjadi $86 \%$; 2) terjadi peningkatan skor dari 2,76 (kualifikasi kurang baik) menjadi 3,87 (kualifikasi baik).
\end{abstract}

Kata Kunci: pembelajaran, project, prestasi belajar, aktivitas siswa

\section{PENDAHULUAN}

Di Indonesia masalah pendidikan masih menjadi salah satu topik pembicaraan yang sangat menarik, baik di masyarakat luas maupun di kalangan para pakar pendidikan. Hal ini merupakan sesuatu yang sangat wajar karena hampir setiap komponen di bangsa ini berkepentingan dan ikut terlibat baik secara langsung maupun tidak langsung dalam proses pendidikan tersebut.

Meningkatnya kualitas pendidikan merupakan tujuan yang diharapkan dalam pembangunan pendidikan nasional kita, sesuai dengan Undang-Undang Nomor 20 tahun 2003 tentang Sistem Pendidikan Nasional.

Seorang guru merupakan pelaku langsung yang berhadapan dengan siswa harus mampu menjadi manajer dalam mengatur strategi sebuah proses belajar mengajar. Oleh karena itu, sebelum melaksanakan tanggung jawabnya sebagai seorang guru, ia harus merencanakan program pembelajaran secara matang berdasarkan pedoman yang berlaku dengan menetapkan tujuan yang akan dicapai dan mengorganisasikan sumber-sumber belajar yang memungkinkan tercapainya 
tujuan secara efektif dan efisien. Guru harus selalu memotivasi dan menstimulasi peserta didik sehingga mereka akan siap dan aktif dalam mewujudkan tercapainya tujuan selama proses pembelajaran (Rianto, 2002)

Guru sebagai pendidik yang berinteraksi langsung dalam proses pendidikan haruslah memahami dan mengupayakan tercapainya tujuan pendidikan tersebut. Namun demikian dapat kita rasakan bersama bahwa hasil pendidikan yang ada saat ini belum sesuai dengan apa yang diharapkan oleh semua pihak. Demikian pula yang terjadi pada hasil belajar siswa dalam pembelajaran Geografi di Sekolah Menengah Atas Negeri (SMAN) 6 Yogyakarta.

Berdasarkan pengamatan, partisipasi siswa dalam kegiatan pembelajaran langsung serta capaian nilai hasil belajar mata pelajaran geografi yang diperoleh siswa masih belum optimal. Hal ini di lihat dari hasil penilaian yang di capai oleh siswa masih banyak yang berada di bawah nilai Kriteria Ketuntasan Minimal (KKM) yang ditentukan. Aktivitas siswa selama kegiatan pembelajaran masih kurang optimal yang diitunjukkan dengan banyaknya siswa yang belum berani mengajukan pertanyaan maupun menjawab pertanyaan yang diberikan oleh guru yang mengakibatkan suasana kelas menjadi pasif, sehingga setelah diadakan penilaian masih banyak siswa yang harus mengikuti kegiatan remidial. Hal ini disebabkan karena proses pembelajaran masih didominasi dengan model konvensional, guru kurang aktif dan kreatif dalam memilih dan menerapkan model pembelajaran dalam setiap kompetensi dasar yang harus dikuasai oleh siswa.

Walaupun secara teoritik telah tersedia cukup banyak model pembelajaran, namun tidak setiap model pasti sesuai dengan kompetensi dasar yang harus di kuasai oleh siswa. Beberapa faktor yang harus dipertimbangkan adalah tujuan pembelajaran, sarana dan prasarana, keadaan siswa, dan lingkungan belajar (Soekamto, $1996: 151$ ).

Pada Mata pelajaran Geografi salah satu materi dasar yang harus dipahami siswa adalah materi dinamika hidrosfer dan pengaruhnya terhadap kehidupan. Pada materi ini sering terjadi masih kurangnya pemahaman siswa dalam memahami dinamika hidrosfer dan pengaruhnya terhadap kehidupan, antara lain disebabkan kurangnya kemampuan guru dalam mengelola kelas serta terbatasnya sarana dan prasarana yang tersedia. Karena materi ini berhubungan dengan kenampakan fisik, maka penyampaian materi ini tidak dapat sekedar disampaikan melalui metode ceramah saja. Untuk memperjelas sebuah konsep mengenai dinamika hidrosfer diperlukan sebuah media pembelajaran pembantu berupa gambar ataupun media. Berkaitan dengan hal itu maka yang perlu diperhatikan oleh seorang guru dalam memilih strategi atau metode belajar mengajar, sehingga proses belajar mengajar menjadi efektif dan efisien untuk mencapai hasil secara optimal.

Dari permasalahan di atas, maka penulis merasa perlu untuk melakukan penelitian tindakan kelas tentang Pembelajaran Berbasis Project untuk Meningkatkan Prestasi Belajar Siswa Pada Mata Pelajaran Geografi Kelas X IPS SMA Negeri 6 Yogyakarta Tahun Pelajaran 2019/2020. Oleh karena itu dalam penelitian ini bertujuan untuk mengetahui peningkatan prestasi belajar siswa 
kelas X IPS Sekolah Menengah Atas (SMA) Negeri 6 Yogyakarta Tahun Pelajaran 2019/2020 dengan pembelajaran berbasis project pada mata pelajaran geografi kompetensi dasar dinamika hidrosfer dan dampaknya terhadap kehidupan serta mengetahui peningkatan aktivitas siswa kelas X IPS SMA Negeri 6 Yogyakarta Tahun Pelajaran 2019/2020 dengan pembelajaran berbasis project pada mata pelajaran geografi kompetensi dasar dinamika hidrosfer dan dampaknya terhadap kehidupan.

\section{Pembelajaran Berbasis Project}

Pembelajaran berbasis project (project based learning) merupakan pendekatan pengajaran komprehensif dimana lingkungan belajar siswa didesain agar siswa dapat melakukan penyelidikan terhadap masalah-masalah autentik termasuk pendalaman materi dari suatu topik mata pelajaran dan melaksanakan lainnya (Nurhadi dan Senduk, 2003: 76).

Pada sistem pengajaran ini siswa diberi tugas yang lengkap, realistis dan kemudian diberikan bantuan secukupnya agar mereka dapat menyelesaikan dengan baik dan siswa mendapatkan gambaran yang terjadi di dalam kehidupan nyata. Tujuan utama pembelajaran ini adalah siswa lebih mandiri dan aktif. Empat prinsip pengajaran project adalah 1) Membuat tugas bermakna, jelas dan menantang 2) menganekaragamkan tugas-tugas guru menentukan variasi tugas yang tidak sama dari hari-kehari 3) menaruh perhatian pada tingkat kesulitan 4) memonitor kemajuan siswa (Arikunto, dkk, 2006 )

Pengajaran project yang dimaksud dalam penelitian ini adalah pengajaran dimana siswa diberikan tugas secara mandiri/kelompok untuk dikerjakan di kelas dan di luar kelas dengan tujuan agar siswa tertantang untuk bekerja secara aktif, mengaplikasikan antara pemahaman teori yang diterima dari guru atau membaca pustaka dengan keterampilan mengaplikasikan secara optimal.

Berikut ini langkah pembelajaran dalam pembelajaran berbasis project 1) menyiapkan pertanyaan atau penugasan proyek 2) mendesain perencanaan proyek 3) menyusun jadwal sebagai langkah nyata dari sebuah proyek 4) memonitor kegiatan dan perkembangan proyek 5) menguji hasil 6) Mengevaluasi kegiatan/pengalaman (Sudjana, 1991).

\section{Prestasi Belajar}

Prestasi adalah hasil yang dicapai individu melalui usaha yang dialami secara langsung dan merupakan aktivitas kecakapan dalam situasi tertentu Witherington (2003: 155). Menurut Murayi (dalam Beck, 1990: 290) mendefinisikan prestasi sebagai berikut: "The overcome abstracles to etercise power, to strive to do something difficult as well and as quickly as possible" dengan kata lain dengan prestasi untuk mengatasi hambatan, melatih kekuatan, berusaha melakukan sesuatu yang sulit dengan baik dan secepat mungkin.

Belajar merupakan suatu proses yang mengakibatkan perubahan dalam diri individu yang belajar, perubahan itu bisa berupa tingkah laku. Hal ini sesuai dengan pendapat Nasution (1980: 68) bahwa belajar adalah change in behavior atau perubahan tingkah laku. 
Menurut Anuri (1989: 42) ada tiga jenis prestasi atau hasil belajar yaitu: (1) total prestasi belajar yaitu tingkat keberhasilan siswa dalam belajar secara keseluruhan. Prestasi ini mencerminkan kemampuan siswa untuk mengingat kembali fakta-fakta dan konsep-konsep serta memahami hubungan antara suatu fakta dengan fakta lainnya; (2) prestasi belajar mengingat dan konsep yaitu tingkat keberhasilan siswa mempelajari suatu mata pelajaran, khususnya dalam aspek mengingat fakta dan konsep; dan (3) prestasi belajar memahami konsep dan fakta yaitu keberhasilan siswa mempelajari suatu mata pelajaran khususnya dalam aspek pemahaman fakta dan konsep.

Untuk mengukur prestasi belajar Geografi yang dikehendaki dalam penelitian ini adalah dengan menggunakan alat evaluasi berupa butir-butir tes. Item tes dibuat sedemikian rupa sehingga dapat menggambarkan prestasi belajar setelah mengikuti kegiatan pembelajaran.

\section{Hidrosfer}

Secara alami, air di Bumi selalu bergerak hingga terbentuk daur atau siklus hidrologi. Selama dalam perjalanan siklus tersebut, air tidak pernah berhenti, hanya akan tertahan sementara dalam berbagai bentuk dan tempat sehingga dapat dimanfaatkan oleh manusia. Pada gambar, unsur-unsur utama siklus hidrologi dapat diamati dengan jelas. Jika salah satu unsur utama tersebut rusak atau terganggu, maka proses yang berlangsung dalam siklus hidrologi juga mengalami gangguan. Gangguan-gangguan ini menimbulkan ketidakseimbangan hidrologi yang akhirnya berdampak pada kehidupan. Selama dalam perjalanan siklus hidrologi, air ada yang tertahan di berbagai tubuh perairan, ada pula yang langsung kembali masuk pada siklus hidrologi. Berdasarkan lama peredaran air, siklus hidrologi dapat dibedakan menjadi tiga, yaitu siklus pendek, sedang, dan panjang.

Adapun unsur-unsur utama (komponen) yang terjadi dalam proses siklus hidrologi, adalah sebagai berikut 1) Evaporasi, merupakan penguapan bendabenda abiotik dan bisa dikatakan sebagai proses perubahan wujud air menjadi gas. Penguapan di Bumi sebagian besar (sekitar 80\%) berasal dari penguapan air laut. 2) Transpirasi, merupakan proses pelepasan uap air yang berasal dari tumbuhtumbuhan melalui bagian daun, terutama stomata atau mulut daun. 3) Evapotranspirasi, merupakan gabungan antara proses evaporasi dan transpirasi. 4) Kondensasi, merupakan proses perubahan wujud uap air menjadi air akibat adanya pendinginan, 5) Adveksi, merupakan proses pengangkutan air dengan gerakan horizontal seperti perjalanan panas maupun uap air dari satu lokasi ke lokasi yang lain oleh gerakan udara mendatar, 6) Presipitasi, merupakan semua bentuk hujan dari atmosfer ke Bumi yang meliputi air, salju, dan es 7) Run Off (Aliran Permukaan), adalah pergerakan aliran air di permukaan tanah melalui saluran sungai maupun anak sungai, 8) Infiltrasi, merupakan perembesan atau pergerakan air ke dalam tanah melalui pori-pori tanah secara vertical, 9) Perkolasi merupakan perembesan atau pergerakan air kedalam tanah melalui pori-pori tanah secara horizontal, 10) Intersepsi, hujan turun di hutan yang lebat, tetapi air tidak sampai ke tanah, akibat intersepsi, air hujan tertahan oleh daun-daunan dan batang pohon (Wardiyatmoko: 2012). 
Keberadaan air menguntungkan manusia karena selain dikonsumsi sebagai kebutuhan hidup, air juga dapat digunakan untuk mengairi sawah, membangkitkan energi listrik, sebagai sarana dan prasarana transportasi, dan sebagai sumber mata pecaharian. Namun dilain pihak, air juga dapat mengancam kehidupan manusia dalam bentuk fenomena banjir dan tsunami. Fenomena fenomena tersebut dapat mengakibatkan kerusakan material hingga menimbulkan korban jiwa.

\section{METODE}

Jenis Penelitian, Jenis penelitian ini adalah Penelitian Tindakan kelas (PTK). Subyek Penelitian, untuk menjawab permasalahan yang telah diuraikan di atas, ada beberapa faktor yang diteliti yaitu: Faktor siswa, faktor siswa yang diteliti adalah: (1) Aktivitas dalam penyelesaian tugas, dan (2) hasil tes penguasaan kompetensi dasar Faktor guru, dari faktor guru yang akan diteliti adalah penerapan pembelajaran berbasis project pada pembelajaran dinamika hidrosfer dan dampaknya terhadap kehidupan

Penelitian ini dilaksanakan pada kelas yang mempunyai rata-rata nilai geografi paling rendah yaitu kelas X IPS SMA Negeri 6 Yogyakarta, yang terdiri dari 10 siswa laki-laki dan 23 siswa perempuan. Rendahnya kemampuan akademik siswa di kelas ini antara lain disebabkan kurangnya motivasi terhadap pelajaran geografi. Hal ini ditunjukkan dengan masih banyaknya siswa yang berbicara diluar materi yang sedang diajarkan saat proses pembelajaran berlangsung. Lokasi Penelitian, Penelitian ini dilaksanakan di SMA Negeri 6 Yogyakarta, Jl. C. Simanjuntak 2 Yogyakarta dan dilaksanakan selama 4 bulan, dari Bulan September 2019 sampai dengan Bulan Desember 2019.

Prosedur penelitian yang dilakukan adalah persiapan tindakan yang mencakup 1) menyusun rencana pembelajaran, 2)menyusun lembar observasi guru dan siswa untuk melihat implementasi penerapan pembelajaranasis project 3) menyusun format catatan kejadian harian untuk mencatat kejadian-kejadian selama pembelajaran 4) menyusun format catatan hasil refleksi untuk mendokumentasikan temuan hasil refleksi 5) menyiapkan sarana berupa: kertas manila, spidol warna, penggaris, isolasi bolak balik 6) Menyusun tes untuk mengukur penguasaan materi / prestasi siswa

Pelaksanaan Tindakan, kegiatan yang dilakukan pada tahap ini guru melaksanakan rencana pembelajaran yang telah disusun, meliputi 1) Kegiatan pendahuluan : motivasi apersepsi, menyampaikan kompetensi dasar dan indikator pembelajaran penjelasan tugas individu/kelompok, 2) Kegiatan inti : Informasi konsep, Penjelasan langkah-langkah kegiatan, penyelesaian tugas, laporan, dan evaluasi tugas, 3) Penutup : membuat rangkuman, memberikan tes, informasi kegiatan yang akan datang

Pemantauan dan Evaluasi, kegiatan yang dilakukan adalah pengamatan kegiatan guru dan kegiatan siswa dalam pembelajaran kompetensi dasar dinamika hidrosfer dan dampaknya terhadap kehidupan yang meliputi : Observasi guru terhadap penerapan model pembelajaran berbasis project, Obsevasi siswa selama 
kegiatan penyelesaian tugas, Observasi siswa dalam penyampaian tugas, Mencatat kejadian penting selama kegiatan berlangsung, melaksanakan tes untuk mengukur prestasi belajar siswa dalam penguasaan kompetensi dasar dinamika hidrosfer dan dampaknya terhadap kehidupan.

Analisis dan Refleksi, hasil observasi kemudian dianalisis oleh kolaborator dan guru akan mengetahui bagaimana penerapan pembelajatan berbasis project, bagaimana keadaan siswa selama mengerjakan tugas dan menyampaikan hasil yang menggambarkan aktivitas siswa serta hasil tes yang menggambarkan prestasi belajar siswa selama pembelajaran berlangsung. Catatan-catatan kejadian menjadi acuan pijakan untuk refleksi dan selanjutnya digunakan pada perencanaan siklus berikutnya.

Siklus Penelitian, penelitian ini akan terbagi dalam dua siklus dan setiap siklus diakhiri dengan tes penguasaan kompetensi dasar dinamika hidrosfer dan dampaknya terhadap kehidupan. Siklus pertama berlangsung 6 jam pelajaran $(2 \mathrm{x}$ pertemuan) dengan materi: (1) Evaporasi, dan (2) Evapotranspirasi (3) Kondensasi (4) Adveksi (5) Presipitasi (6) Infiltrasi (7) Perkolasi (8) Run Off (9) Kristalisasi. Siklus kedua berlangsung selama 6 jam pelajaran ( 2 x pertemuan) dengan materi: Macam macam siklus Hidrosfer ( Siklus Pendek, Siklus sedang, Siklus Panjang ). Pada tiap akhir siklus diadakan analisis dan refleksi untuk menganalisis keberhasilan maupun kecenderungan yang terjadi. Pembagian siklus didasarkan pada sub materi pembelajaran dan pada setiap akhir siklus diadakan tes penguasaan kompetensi dasar.

Teknik Pengumpulan Data, sumber data yang dipakai adalah siswa, peneliti dan kolaborator teknik pengambilan data: data penerapan metode pembelajaran berbasis project diperoleh dengan lembar observasi guru dan lembar observasi aktivitas siswa, data prestasi belajar diperoleh dengan menggunakan tes penguasaan kompetensi dasar.

Metode Analisis Data, untuk menentukan peningkatan prestasi belajar siswa dalam pembelajaran dinamika hidrosfer dan dampaknya terhadap kehidupan digunakan tes tertulis yang diujikan setelah tindakan dengan batas minimal sesuai dengan KKM (kriteria ketuntasan minimal). Besarnya KKM untuk mata pelajaran Geografi kelas X IPS yaitu 75, untuk menentukan keberhasilan penerapan metode pembelajaran berbasis project digunakan skala likert dengan empat pilihan yaitu sangat baik, baik, kurang baik, atau sangat kurang baik terhadap 12 aspek kegiatan guru dan 5 aspek aktivitas siswa. Jumlah skor yang diperoleh dari observasi guru dan siswa ditentukan kategori sebagai berikut: (1) $4.00-5.00$ sangat baik, (2) 3.00 - 3.99 baik, (3) 2.00 - 2.99 kurang baik, dan (4) 1.00 1.99 sangat kurang baik.

Indikator keberhasilan penelitian ini adalah: 1) Adanya peningkatan prestasi belajar siswa yang ditunjukkan dengan hasil tes penguasaan kompetensi dasar yang diperoleh mencapai $\geq 75$ sebanyak $\geq 75 \%$ setelah dilakukan tindakan selama 2 siklus. 2) Adanya peningkatan aktivitas siswa yang ditunjukkan dengan peningkatan skor aktivitas hingga mencapai rerata $\geq 3,00$ atau kualifikasi baik. Apabila prestasi yang diperoleh siswa setelah dikenai tindakan mengalami peningkatan seperti yang diharapkan berarti hipotesis tindakan terbukti. 


\section{HASIL PENELITIAN DAN PEMBAHASAN}

Pada bab sebelumnya telah diuraikan bahwa permasalahan dalam penelitian ini adalah prestasi belajar siswa yang rendah dan pembelajaran masih bersifat konvensional. Oleh karena itu perlu pemilihan strategi pembelajaran yang tepat untuk memecahkan masalah tersebut. Strategi yang dimaksud adalah pembelajaran berbasis project ( project based learning ).

Berdasarkan hasil pemantauan dan evaluasi menunjukkan bahwa pembelajaran berbasis project yang berlangsung sebanyak dua siklus terlihat bahwa ada dampak positif pada aktivitas siswa, yaitu terlihat hasilnya menjadi lebih baik, cara kerja mulai terstruktur, komunikasi interaktif antara siswa dan guru terealisir, siswa merasa tidak tegang dengan pemberian tugas dari guru. Meskipun secara keseluruhan tindakan, belum menunjukkan hasil yang maksimum namun, setelah diakhir siklus, terlihat bahwa tugas-tugas yang diberikan dari oleh guru kepada siswa bisa difahami dengan cepat, dikerjakan dengan sempurna, aktivitas siswa menjadi lebih baik dan prestasi belajar siswapun menjadi meningkat. Perubahan ini terjadi pada siklus kedua. Siswa terlihat sudah mulai mudah memahami konsep materi yang disampaikan oleh guru. Pemahaman karakteristik terhadap tugas sudah lebih baik. Kenyataan ini didukung dengan cara kerja siswa pada saat dihadapkan dengan tugas menggambar siklus hidrosfer. Siswa sudah tidak canggung lagi untuk terbuka menyampaikan hal-hal yang tidak dimengerti secara langsung. Situasi pembelajaran terlihat kondusif

Pada pertemuan akhir siklus, siswa mampu menganalisis manfaat hidrosfer dan dampaknya terhadap kehidupan. Siswa juga mampu menyadari bahwa air merupakan kebutuhan manusia yang sangat penting untuk kebutuhan sehari-hari, sehingga kelangsungan hidupnya menjadi lebih baik.

Pemahaman tentang siklus hidrosfer yang dilakukan siswa secara langsung akan mempermudah pemahaman dinamika hidrosfer dan dampaknya terhadap kehidpan manusia. Aktivitas siswa lebih baik, lebih mudah penguasaan kompetensi dasar, dan prestasi belajar lebih baik. Secara rinci peningkatan skor aktivitas siswa disajikan para tabel berikut:

Tabel 1. Peningkatan Skor Aktivitas Siswa pada Siklus

$\begin{array}{clcc}\text { No } & \text { Aspek Pengamatan } & \text { Siklus I } & \text { Siklus II } \\ 1 & \text { Pemahaman Konsep } & 2,64 & 3,82 \\ 2 & \text { Karakteristik Tugas } & 2,85 & 3,79 \\ 3 & \text { Cara Kerja } & 2,75 & 3,86 \\ 4 & \text { Hasil Kerja } & 2,78 & 3,96 \\ 5 & \text { Laporan Tugas } & 2,79 & 3,94 \\ & \text { Jumlah } & 13,81 & 19,34 \\ & \text { Rerata } & 2,76 & 3,87 \\ & \text { Kualifikasi } & \text { Kurang Baik } & \text { Baik }\end{array}$

Untuk mengetahui peningkatan prestasi belajar siswa, dilakukan tes penguasaan kompetensi dasar pada akhir siklus. Tes yang diberikan pada akhir siklus pertama berbentuk uraian singkat dengan jumlah soal 8 nomor, hasil yang diperoleh menunjukkan bahwa ketuntasan belajar dari 33 siswa terdapat 18 siswa ( $54 \%$ ) yang mencapai nilai diatas kriteria ketuntasan minimal KKM (75) 
Sedangkan pada tes yang diberikan untuk siswa pada akhir siklus kedua berbentuk soal pilihan ganda dengan jumlah soal 10 nomor. Terlihat hasilnya menunjukkan bahwa ketuntasan belajar dari 33 siswa terdapat 29 siswa ( $86 \%$ ) dan yang mencapai nilai diatas kriteria ketuntasan minimal KKM (75). Dapat dilihat secara rinci peningkatan prestasi belajar siswa selama dua siklus disajikan pada tabel berikut:

Tabel 2. Peningkatan Prestasi Belajar Siswa

\begin{tabular}{cccccc}
\multirow{2}{*}{ No } & \multirow{2}{*}{ Nilai } & \multicolumn{2}{c}{ Ketuntasan } & \multicolumn{2}{c}{ Persentase } \\
& & Siklus I & Siklus II & Siklus I & Siklus II \\
1 & $\geq 75$ & 18 & 28 & $54 \%$ & $86 \%$ \\
2 & $<75$ & 15 & 5 & $45 \%$ & $14 \%$ \\
Jumlah & 33 & 33 & $100 \%$ & $100 \%$
\end{tabular}

Sedangkan untuk peningkatan aktivitas dan prestasi belajar siswa dapat divisualisasikan dalam histogran berikut:
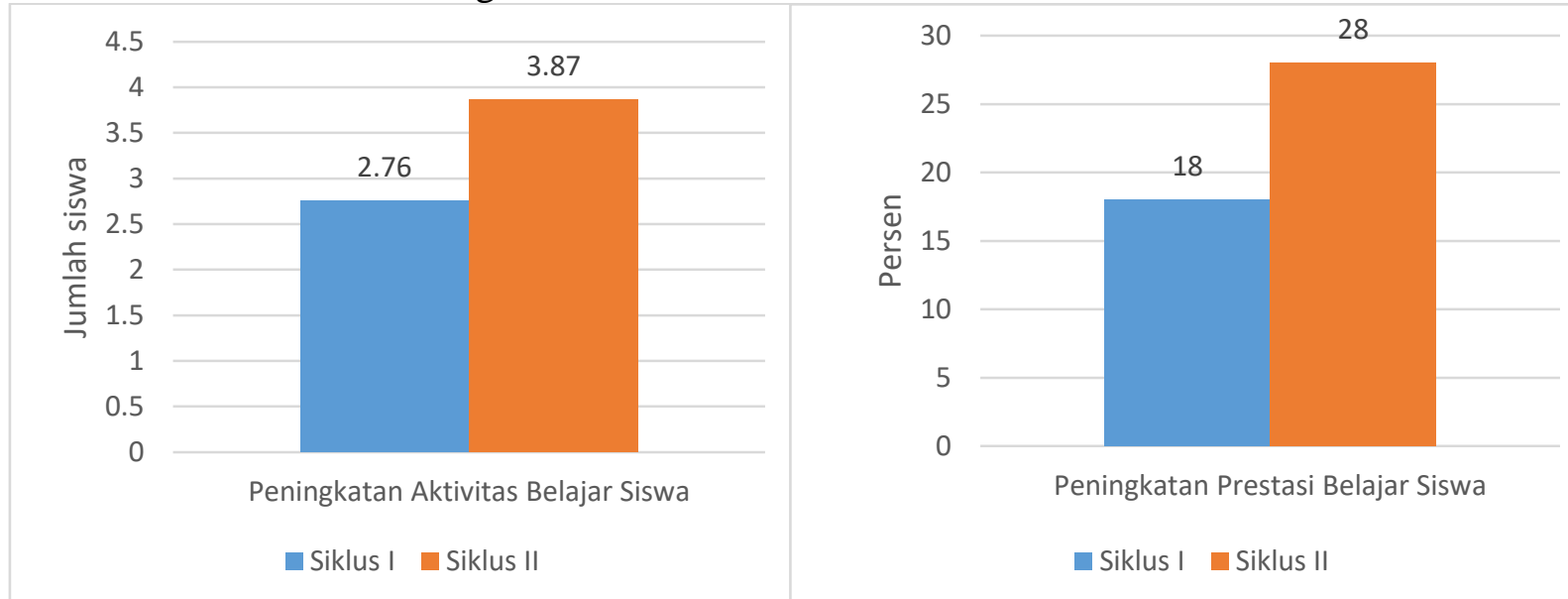

Gambar 1. Histogram Peningkatan Aktivitas dan Prestasi Belajar Siswa

Berdasarkan hasil penelitian tindakan kelas yang telah peneliti lakukan, maka dapat dilihat bahwa pada pembelajaran berbasis project dapat meningkatkan prestasi belajar siswa dalam mata pelajaran geografi pada kompetensi dasar dinamika hidrosfer dan dampaknya terhadap kehidupan.

Dengan demikian hipotesis penelitian yang menyatakan bahwa pembelajaran berbasis project dapat meningkatkan prestasi belajar siswa pada mata pelajaran geografi khusus kompetensi dasar dinamika hidrosfer dan dampaknya terhadap kehidupan pada kelas X IPS Sekolah Menengah Atas (SMA) Negeri 6 Yogyakarta dapat terbukti, disamping itu pembelajaran berbasis project juga dapat meningkatkan aktivitas siswa dalam mengikuti pembelajaran geografi pada kompetensi dasar dinamika hidrosfer dan dampaknya terhadap kehidupan juga terbukti.

\section{SIMPULAN}

Berdasarkan hasil observasi dan hasil tes penguasaan kompetensi dasar dinamika hidrosfer dan pengaruhnya terhadap kehidupan pada tiap siklus yang telah dikemukakan pada pembahasan dan bab terdahulu, maka dapat ditarik 
kesimpulan bahwa 1) Pembelajaran berbasis project dapat meningkatkan prestasi belajar pada mata pelajaran geografi khusus kompetensi dasar dinamika hidrosfer dan dampaknya terhadap kehidupan siswa kelas X IPS Sekolah Menengah Atas Negeri 6 Yogyakarta Tahun Pelajaran 2019/2020, terbukti ada peningkatan presentase ketuntasan belajar siswa dari 54\% pada kegiatan siklus I menjadi $86 \%$ pada kegiatan akhir siklus II. 2) Pembelajaran berbasis project dapat meningkatkan aktivitas belajar siswa dalam mengikuti pembelajaran geografi pada kompetensi dasar dinamika hidrosfer dan dampaknya terhadap kehidupan kelas X IPS Sekolah Menengah Atas Negeri 6 Yogyakarta Tahun Pelajaran 2019/2020, terbukti dari 33 siswa yang aktivitasnya kurang baik pada kegiatan siklus I dengan rerata skor 2,76 kualifikasi kurang baik mengalami peningkatan pada akhir siklus II menjadi 3,87 dengan kualifikasi baik.

Berdasarkan hasil penelitian di atas, maka : 1.) pembelajaran berbasis project hendaknya dikembangkan dan dilaksanakan dalam proses pembelajaran mata pelajaran geografi di SMA agar ada peningkatan prestasi belajar siswa. Konsekuensinya guru harus memahami langkah-langkah pembelajaran barbasis project dengan baik dan mengembangkan secara variatif, menyenangkan, dan menantang. 2) pembelajaran berbasis project hendaknya dikembangkan dan dilaksanakan dalam proses pembelajaran mata pelajaran geografi di SMA agar ada peningkatan aktivitas siswa dalam melakukan pembelajaran, maka dalam pembelajaran para siswa dihadapkan dengan tugas-tugas yang terstruktur, variatif, dan proporsional. 1) hambatan-hambatan dalam pembelajaran berbasis project dapat diminimalisir melalui perencanaan yang baik dan terstruktur.

Kepada guru-guru geografi dapat melakukan kegiatan penelitian tindakan kelas untuk dapat memecahkan masalah-masalah yang dihadapi, kepada pengelola sekolah, hasil penelitian ini hendaknya dapat digunakan sebagai dasar penentuan kebijakan yang berkaitan dengan pengembangan profesi guru dan peningkatan kualitas pembelajaran

\section{DAFTAR PUSTAKA}

Anuri, E. (1989). Efektifitas Pendekatan Belajar Siswa Aktif Untuk Meningkatkan Prestasi Belajar Sejarah. Studi Eksperimen di SMA Negeri Kotamadya Padang. Jakarta: Tesis PPS IKIP Jakarta.

Arikunto, S., dkk. (2006). Penelitian Tindakan Kelas. Jakarta: Bumi Aksara.

Beck, R. C. (1990). Motivation Theories and Principles. Englewod Cliffs NJ: Prentice Hall.

Nasution, S. (1980). Dedaktik Azaz-Azaz Mengajar. Bandung: Jrmmars

Nurhadi \& Senduk, A.G. (2003). Pembelajaran Kontekstual. Malang: Universitas Negeri Malang.

Rianto, M. (2002). Pendekatan dan Metode Pembelajaran. Jakarta: Depdiknas Proyek Peningkatan Pusat Pengembangan Penataran Guru IPS dan PMP Malang.

Soekamto, T. (1996). Teori Belajar dan Model-Model Pembelajaran. Jakarta: Dirjen Dikti Depdikbud. 
Sudjana, N. (1991). Penilaian Hasil Belajar Mengajar. Bandung: Remaja Rosdakarya

Wardiyatmoko, K. (2012). Geografi untuk SMA/MA kelas X jilid 1. Jakarta: Erlangga

Witherington (2003). Psikologi Pendidikan. (Terjemahan M Ngalim Purwanto). Jakarta: Remaja Rindu Jaya. 